Metodički obzori 8(2013)1

UDK: 376.1-056.45

Pregledni rad

Primljeno: 11. 6. 2011.

\title{
IZAZOVI UČITELJA U RADU S DAROVITOM DJECOM
}

\author{
Mr. sc. Lejla Karijašević, \\ Filozofski fakultet u Sarajevu \\ (Bosna i Hercegovina) \\ e-mail: lejla.karijasevic@ff.unsa.ba
}

\begin{abstract}
Sažetak
Nadareno dijete je izazov za cjelokupni školski sistem, a posebno za nastavnika. Mnogo je razloga za to: nadareno dijete treba više poticaja, znanja, aktivnosti; nastavnik treba da je spreman na različite situacije, pitanja, odgovore nadarenog djeteta; zabilježene su i situacije u kojima nadareno dijete zna više o nekoj temi od nastavnika; postoje određeni metodički oblici rada s nadarenom djecom koje nije jednostavno organizirati i realizirati, a nastavnik u tome ima glavnu ulogu. Ovi i mnogi drugi razlozi upućuju da nije jednostavno poučavati nadarenu djecu, ali je to iznimno važno i neophodno.

Odgovor na pitanje ko je nadareno dijete nije jednostavno dati. Autori navode različite karakteristike koje izdvajaju nadarenu od prosječne djece. Karakteristike nadarenih su važne da bi bili prepoznati, identificirani i uključeni u adekvatan odgojno-obrazovni rad u školi, u kojem je izražena individualizacija i diferencijacija. Ovo se može ispoštovati u razredu primjenom nastavnih listića R. Dottrensa, gdje se posebno izdvajaju listići za razvoj. Primjenom nastavnih listića može se izbjeći da nadarenima bude dosadno u školi.
\end{abstract}

Ključne riječi: nadareno dijete, izazov, nastavnik, dosada, individualizacija, diferencijacija, nastavni listići

\section{Uvod}

Darovite osobe trebaju kontinuiranu, specifičnu i vrlo konkretnu pomoć. One trebaju materijalnu podršku, kvalitetno poučavanje, potrebno znanje, primjer koji će slijediti bar da bi otkrili nove puteve kako se stvari mogu raditi i, naravno, ono što je potrebno svima, a to je emocionalna podrška (Freeman, 2001).

Pravovremena identifikacija, kvalitetan odgojno-obrazovni rad, te pozitivan odnos sredine prema nadarenim osobama ključni su u cjelokupnom radu s ovom djecom. McGuigan (1991; prema: Young, \& Tyre, 1992), u longitudinalnoj studiji o učenicima visokih intelektualnih sposobnosti, došao je do zaključka da se veliki broj ove djece gubi, jer ona napuštaju školu. Postavlja se pitanje: zašto bi dijete iznadprosječnih sposobnosti napustilo školu ukoliko školski program može savladati sa pola muke? Odgovor se krije u neprepoznavanju njihovih iznadprosječnih sposob- 
nosti i nezadovoljavanju osnovnih potreba ove djece! Veliki problem nadarenih učenika u školi je dosada. Oni, često, već znaju ono što se uči u školi i/ili stvari vrlo brzo razumijevaju, tako da im je višestruko ponavljanje istih stvari suvišno i dosadno.

Učitelj ${ }^{1}$ ima važnu ulogu u cjelokupnom radu s nadarenim učenicima u školi. Bitan je u svim fazama rada: prepoznavanju, identifikaciji i odgojno-obrazovnom radu. Postoji više mogućnosti za organizaciju primjerenog odgojno-obrazovnog rada za nadarene učenike, ali nastavnik može i samostalno kreirati radnu atmosferu u kojoj se poštuje individualizacija i diferencijacija.

Nadareno dijete, dakle, treba više znanja, podrške, pažnje i rada, s obzirom da su njegove sposobnosti iznad onoga što je postavljeno normama i što se nudi u školi. Ukoliko se ne odgovori na potrebe nadarene djece, oni mogu postati djeca s problemima u ponašanju i tada im je iz drugog razloga potrebna posebna pomoć.

Zbog navedenog, nadarena djeca su djeca s posebnim potrebama!

\section{Karakteristike nadarene djece}

Dugo je bio prisutan stav da su nadarena djeca emocionalno nestabilna, slaba, bolešljiva. Ovaj stav je proizilazio iz više razloga. Prvo, u kasnim 1800-tim i početkom 1900-tih godina napisane su brojne rasprave o tome kako između genijalaca i psihički oboljelih osoba postoji povezanost; drugo, neke od ranijih studija uključivale su samo djecu sa ekstremno visokim IQ-om (ove studije nisu uključivale djecu koja su sveobuhvatno prezentirala nadarenost); treće, moguće je naći neke slučajeve nadarenih i talentiranih koji su bili ekscentrični ili su imali emocionalnih problema (npr.Vincent Van Gogh). Ti pojedini slučajevi čine da ljudi zaključuju kako su sve nadarene osobe uvijek nastrane. Danas se smatra da nadarena djeca teže da budu zdrava, tjelesno i emocionalno, i da postižu odlične rezultate više nego u jednom području. Ipak, postoji mogućnost da se sada stvori slika da su nadareni i talentirani oni koji sve mogu napraviti odlično i nikada nemaju emocionalne ili tjelesne probleme. Nadarene i talentirane osobe - iako kao grupa u mnogim karakteristikama mogu biti superiorni naspram prosječnih osoba - individue su koje mogu biti i tjelesno i emocionalno ugrožene (Kneedler i sar.; 1984).

Pod terminom nadarena djeca Winner (1996; prema: Cvetković-Lay, 2002.) podrazumijeva one koji imaju tri karakteristične i atipične osobine u odnosu prema ostaloj djeci:

1. Rano sazrijevanje. Nadareno dijete počinje ovladavati nekim područjem znatno prije prosjeka svoje dobne skupine. Ono, osim toga, mnogo brže napreduje u određenim područjima od prosječnog djeteta, ponajviše zato što mu je učenje i ovladavanje vještinama u tim područjima ${ }^{2}$ mnogo brže i lakše. ${ }^{3}$

\footnotetext{
${ }^{1}$ Pod pojmom učitelj razumijevamo slijedeće: učitelj, nastavnik, profesor, dakle svi oni koji poučavaju u školi.

2 podrazumijeva se skup organiziranog znanja, kao što su jezik, matematika, muzika, umjetnost, šah, balet, gimnastika, tenis, itd.
} 
2. Otpočetka pjevaju svoju pjesmu. Nadarena djeca ne samo što uče brže od prosječne, pa čak i bistre ${ }^{4}$ djece, nego uče i na kvalitativno različit način. Njima treba minimum pomoći ili potpore odraslog da bi ovladala područjem svog intenzivnog interesa, i veći dio vremena ona uče samostalno. Nadarena djeca često samostalno utvrđuju nova pravila u području kojim ovladavaju i nove, osebujne načine rješavanja problema unutar tog područja. Sve to znači da su nadarena djeca, po definiciji, i kreativna.

3. Zanos u ovladavanju vještinama. Nadareno dijete ima snažnu unutrašnju motivaciju za ovladavanjem i osmišljavanjem područja u kojemu pokazuje napredan razvoj. Ono očituje vrlo intenzivan, gotovo opsesivan interes, sposobnost snažnog usredotočenja na ono što je predmet interesa, i strast, zanos u njegovu ovladavanju. Ta sretna kombinacija opsesivnog interesa za određeno područje, zajedno s lakoćom učenja, vodi ga u visoka postignuća.

O superiornim karakteristikama nadarenih spram prosječnih osoba pisali su i Sternberg i Rogers (1986; prema: Cvetković-Lay, 1998). Otkrili su da je razlika u:

1. brzini prepoznavanja problema koje treba riješiti,

2. spremnosti i spontanosti u pronalaženju cijelog niza mogućih rješenja,

3. postavljanju prioriteta u mogućim smjerovima rješavanja problema,

4. selekciji značajnih informacija za rješavanje problema (na razini odraslog stručnjaka),

5. odlučivanju koje je resurse nužno predvidjeti u rješavanju problemskog zadatka,

6. sistematskom nadziranju rješenja,

7. duljem vremenu prethodnog razmatranja i analiziranja problema.

To znači da su nadarena djeca sposobna, sveobuhvatnije od prosječne ${ }^{5}$, sudjelovati u aktivnostima rješavanja problema i planiranju.

Koren (1989) smatra da se osobine nadarenih učenika po kojima se oni, manje ili više, razlikuju od ostalih učenika mogu podijeliti u četiri grupe:

- karakteristike učenja: brzo uočavanje činjenica, neovisnost mišljenja, čitanje knjiga složenijeg sadržaja, izrazita informiranost, kritičko zapažanje i slično;

- karakteristike stvaralaštva: originalnost predodžbi, mnoštvo ideja, sklonost riziku, izbjegavanje rutinskih aktivnosti, neuobičajeni i mudri odgovori i slično;

${ }^{3}$ iznimke su uvijek moguće, što govori i primjer genija koji nisu očitovali rano sazrijevanje

${ }^{4}$ Cvetković-Lay, J. (1998) navodi elemente po kojima se mogu razlikovati bistra i nadarena djeca. Izdvajamo neke od njih: bistro dijete: zna odgovore; ima dobre ideje; s lakoćom uči; tačno kopira zadano; prima informacije, upija ih; voli izlagati u dijelovima; živahno je pri promatranju; zadovoljno je vlastitim učenjem, postignućem. Nadareno dijete: postavlja pitanja; ima neobične ideje; već zna; kreira nova rješenja; služi se informacijama; u izlaganju teži kompleksnosti; pažljiv je posmatrač; vrlo je samokritično.

${ }^{5}$ Osnovna razlika između visokointeligentnih i drugih je u načinu na koji oni postupaju sa informacijama, obično još od najranije dobi. Oni su sposobniji da nađu najbolji način za upotrebu informacija, fleksibilniji su i brži, tako da sve to rezultira većom efektivnošću (Freeman, 2001). 
- socijalne karakteristike: odgovornost, suprotstavljanje autoritetu, podrška ravnopravnosti, adaptabilnost različitim situacijama i slično;

- motivacijske karakteristike: samokritičnost, težnja savršenstvu, ustrajnost u aktivnostima, intrinzičnost poticaja, zanimanje za probleme drugih i slično.

Karakteristike po kojima se nadareni razlikuju od prosječne djece mogu biti uzete kao kriterij pri prepoznavanju i identifikaciji nadarene djece, posebno u razredu gdje je moguće odmah praviti usporedbu između prosječne i nadarene djece.

U odgojno-obrazovnom radu s nadarenim učenicima nisu bitne samo osobine ovih učenika, već i osobine onih koji ih poučavaju.

\section{Osobine nastavnika nadarenih učenika}

U prepoznavanju, identifikaciji i odgojno-obrazovnom radu s nadarenom djecom učestvuju i nastavnici. Nastavnik, općenito, treba da je karakterna osoba, da ima adekvatno opće i stručno obrazovanje, da je pedagoško-psihološki i metodičkodidaktički osposobljen, da ima pravilan odnos prema radu, da voli svoj poziv, da poštuje dječiju ličnost, da kreativno pristupa nastavi, da bude pozitivan uzor djeci. Nastavnikov rad nije samo u okvirima nastave, nego je on odgovoran za cjelokupni razvoj mlade, kritičke i stvaralačke ličnosti (Ajanović i Stevanović, 1998).

Da li se nastavnik nadarenih učenika po svojim osobinama razlikuje od nastavnika koji poučava prosječnu djecu?

Nadareni učenici predstavljaju izazov za nastavnike tokom cijele školske godine zbog nivoa informacija i stepena kreativnosti koje moraju donijeti u razred. Jednostavno vođenje produktivne diskusije $s$ nadarenim učenicima je zahtjevan zadatak za svakog nastavnika. Njihove izražene sposobnosti i neobični ili napredni interesi traže nastavnike koji su inteligentni, kreativni i motivirani.

Nastavnici nadarene djece trebali bi da budu sposobni u procjeni učeničkih sposobnosti, interesa i posvećenosti zadatku te spremni da pomognu jedni drugima da prepoznaju karakteristike koje ukazuju kako neko dijete ima iznadprosječne sposobnosti, te da će imati koristi od specijalnog odgojno-obrazovnog rada. Samo nastavnici s širokim interesima, dobro informirani i s bogatom kreativnom energijom, bit će sposobni za identifikaciju, poučavanje i vođenje nadarenih učenika (Hallahan i Kauffman, 1997).

Feldhusen (1997; prema: Chan, 2001) našao je u svom istraživanju da učitelji nadarenih učenika imaju slične karakteristike kao i nadareni učenici. U te karakteristike spadaju: visoka inteligencija, orijentacija ka postignuću, znanju i fleksibilnosti, postojanje kulturnih i intelektualnih interesa, poštivanje individualnih razlika, dobar odnos s nadarenima.

Whitlock i DuCette (1989; prema: Hallahan i Kauffman, 1997) ističu da sljedeće karakteristike izdvajaju nastavnike nadarenih učenika:

1. entuzijazam i posvećivanje radu s nadarenim učenicima,

2. povjerenje u njihovu sposobnost, 
3. vještina da se drugi ljudi razviju i podstaknu kao izvori i učenici,

4. sposobnost da primijeni znanje iz teorije u praksu,

5. jaka orijentacija ka postignuću.

Neke od osobina nastavnika nadarenih učenika, koje navode ovi autori, spominje i Ewgblada (1987). Ona smatra kako je neophodno da nastavnici koji rade s nadarenim učenicima imaju odgovarajuće osobine, a iz njene rasprave izdvajamo da: poučavajući, nastavnici trebaju pomoći nadarenim učenicima da otkriju kako pronaći put do zadovoljavanja vlastitih interesa, a ne da im samo nastavnici budu izvori znanja, te da svaki nastavnik posjeduje entuzijazam za traženje novih ideja i da bude model za traženje novih znanja.

S druge strane, Baldwin (1993; prema: Hallahan i Kauffman, 1997) ističe da svi stručni nastavnici, vjerovatno, posjeduju osnove gore navedenih osobina i da su, na mnogo načina, izvrsni nastavnici nadarenih učenika veoma slični izvrsnim nastavnicima svih ostalih učenika.

Istraživači se slažu da samo istinski nastavnici mogu adekvatno poučavati nadarenu djecu. Oni navode i različite osobine koje posjeduju takvi nastavnici, kao što su, npr.: entuzijazam, kreativnost, fleksibilnost i slično. Neki autori (npr. Baldwin, 1993) smatraju da svi stručni i kvalitetni nastavnici imaju osobine koje su poželjne za poučavanje nadarene djece. Ovo je dobar zaključak, jer možemo reći da svaki istinski, kvalitetan, stručan nastavnik može poučavati svu djecu, pa tako i nadarenu djecu. On ima potrebno znanje, ali i pedagošku, te metodičko-psihološku osposobljenost.

Nije mu dovoljno znati da zna, već traga i za načinima i metodama razvijanja znanja i mnogobrojnih karakternih i moralnih osobina i kod učenika, poštujući njihove individualne sposobnosti, znanje, interese i potrebe. Nadarena djeca trebaju takvog nastavnika. ${ }^{6}$

Nadareni učenici mogu uzrokovati kod nastavnika posebne osjećaje, koji ih mogu podstaći na kvalitetniji rad, ali i uticati na njihovo cjelokupno djelovanje. Greenhalgh (1994; prema: Dean, 1996) navodi nekoliko izraženih osjećanja:

- razočarenje zbog osjećaja da je potrebno dodatno naporno raditi da bi se obezbijedilo poboljšanje aktivnosti,

- osjećaj prijetnje od strane intelektualno superiornijih učenika i/ili verbalnih konflikata,

\footnotetext{
${ }^{6}$ Nastavni plan i program studija koji primarno obrazuje nastavnike (i druge djelatnike koji učestvuju u odgojno-obrazovnom radu) treba imati sadržaj koji se odnosi na prepoznavanje, identifikaciju i odgojno-obrazovni rad s nadarenim učenicima. Dovoljno je da u školi radi samo jedno stručno lice, posebno od nastavnika, koje nije osposobljeno za rad s nadarenim učenicima, pa da izgubimo vrijedne osobe. Kako ističe Cvetković-Lay, u Hrvatskoj je situacija sljedeća: “...30 do 50 posto populacije školske djece ima pojedine talente, a čak deset posto ih je darovito. U mnogim slučajevima učitelji ne znaju prepoznati darovito dijete, i potreban im je sustav dodatne izobrazbe učitelja za prepoznavanje i rad s darovitom djecom...", zaključuje Cvetković-Lay (2002), naglašavajući da nadarena djecu nisu uvijek odlična, te ističući društvenu ravnodušnost prema ovoj kategoriji djece. Ovo potvrđuje i izjava jednog nadarenog učenika u Hrvatskoj, koji kaže da mu pamet samo smeta, aludirajući da je sve što kaže veliki problem (www.nadarenost.net). Kakva je situacija kod nas?
} 
- stimuliranost intelektualnim izazovom i znatiželjom učenika,

- osjećaj krivnje zbog toga što ne potiču učenike onoliko koliko bi trebali,

- teško razumijevanje učenika koji su kreativni i rade na neki drugi način,

- zavist zbog toga što vlastiti talenti nisu razvijeni tako dobro kao kod učenika,

- nervoza što ne znaju potrebe i principe razvoja učenika,

- zaštitničko ponašanje prema nadarenim učenicima, drugačije nego prema njihovim vršnjacima,

- zadovoljstvo, jer učenicima dijele snažan entuzijazam za predmet koji predaju,

- zbunjenost zbog pogrešnih okvira motivacije učenika, uprkos njihovoj sposobnosti da urade ono što se od njih traži,

- divljenje prema dostignućima učenika,

- osjećaj sažaljenja prema učenicima zbog njihovog odnosa s vršnjacima,

- zabrinutost, jer iako se učenici čine intelektualno nadarenima, izgleda da ne izlaze na kraj sa svojim emocijama.

Mogo je, dakle, različitih osjećanja koja nadarena djeca mogu izazvati kod nastavnika. Zbog ovoga, ali i cijelog niza drugih pitanja i događanja, nije najjednostavnije organizirati i realizirati odgojno-obrazovni rad za nadarenu djecu. Ona su, uglavnom, izazov za školski sistem.

\section{Nadareni učenici u školi}

Postoje različiti metodički oblici koji se primjenjuju u radu s nadarenim učenicima. Ipak, sva razmatranja o odgojno-obrazovnom radu sa nadarenima mogu se svesti na tri, najčešće primijenjena, oblika rada, a to su: grupiranje, akceleracija i obogaćivanje. Ukratko ćemo samo prikazati ova tri oblika rada.

Grupiranje je oblik odgojno-obrazovnog rada koji pretpostavlja okupljanje učenika sličnih sposobnosti na jedno mjesto (Maksić; 1998). U osnovnoj školi grupiranje se može organizirati u obliku posebnih odjeljenja, programa za uzimanje učenika iz redovne nastave i kao klaster-grupiranje po aktivnostima. Dodatne metode grupiranja u višim razredima osnovne škole i u srednjoj školi čine sljedeće mogućnosti:

- specijalizirane škole, posebni nagradni časovi za odlične učenike,

- grupiranje u okviru redovnog razreda, klaster-planiranje jezgra

- kursa i seminari, centri sa posebnim izvorima, specijalni časovi izvan svakodnevnih školskih obaveza, ljetne institucije, posebni programi ljetne ekspedicije i produženi programi u okviru zajednice.

Školska akceleracija je “...ubrzano napredovanje učenika iz razreda u razred, tzv. preskakanje razreda, odnosno ubrzano apsolviranje semestra na višim i visokim školama" (Franković i Pregrad, 1963:23). Svrha školske akceleracije je adekvatnije ostvarivanje didaktičkog načela individualizacije nastave, tj. uvažavanje u nastavi 
individualnih razlika među učenicima, s obzirom na njihove psihofizičke sposobnosti, tempo rada, radno iskustvo, mogućnost usvajanja znanja, način reagiranja, itd. Smisao ideje o školskoj akceleraciji je da se nekim učenicima omogući brže napredovanje iz razreda u razred. Akceleracija može biti ostvarena i upisivanjem djeteta jednu godinu ranije u školu, te orijentirana samo na jedno područje (npr. matematika ili likovni odgoj) i njegovo brže apsolviranje.

Obogaćivanje podrazumijeva dodatno angažiranje učenika u nastavi i van nje. U slučaju kada su nadareni učenici u odjeljenjima sa ostalim učenicima, najčešće im se izvan redovne nastave, uz ili umjesto pojedinih njenih dijelova, nude razne mogućnosti za dodatni rad, rad u sekcijama, učešće na takmičenjima, rad sa mentorom, samostalni rad, itd. Drugi način je da se, u okviru diferencijacije nastave obaveznih programa i individualizacije nastave, obezbijede (kompleksniji, širi) sadržaji na odgovarajućem (višem) nivou. Osnovni problem s obogaćivanjem za visokosposobne je manjak jasnih ciljeva. Stoga, navodimo tri veoma važna cilja obogaćivanja (Freeman, 1991; prema: Cvetković-Lay, 1998): proširivanje sposobnosti za analizu i rješavanje problema; razvoj temeljnih, vrijednih interesa; podsticanje orginalnosti, inicijative i samousmjerenja. U našem školskom sistemu, kao jedan od oblika obogaćivanja, primjenjuje se dodatna nastava. Ova nastava je namijenjena nadarenim učenicima, onima koji iskazuju izrazitije sposobnosti u pojedinim nastavnim disciplinama i oblastima, kao i posebne potrebe, sklonosti i interesiranja. Ovaj oblik nastave ne podrazumijeva prosto povećanje i proširivanje znanja, već njegovo produbljivanje, sagledavanje uzročno-posljedičnih veza i odnosa, uviđanje odnosa među stvarima i pojavama, pronalaženje uzroka i novih, drugačijih i originalnih rješenja. Riječ je o maksimalnoj aktivizaciji učenika, njihovom aktivnom učešću u procesu prerade dobijenih informacija, razvijanju aktivnog i samostalnog kritičkog i stvaralačkog mišljenja, razvijanju kreativnosti. Nažalost, u našim školama, kako ističe Muminović (2000), ovaj oblik nastave je pogrešno shvaćen i neadekvatno iskorišten.

Suština poučavanja je u komunikaciji. Komunikacija u razredu mora biti dvosmjerna, jer i nastavnici mogu učiti od svojih učenika. Nadareni učenici, baš kao i sva ostala djeca, imaju potrebu za poučavanjem koje će podupirati njihov razvoj intelektualni, emocionalni i duhovni. Osim toga, nadareni učenici poštuju nastavnike koji su spremni da ih slušaju jednako kao što i sami govore. Oni trebaju čuti kada su nešto uradili ispravno ili pogrešno, $i$ osjetiti da je nekome stalo do njihovog rada. Ukoliko je poučavanje slabo, moguće je da učenici nekada pretrpe nepotrebnu intelektualnu frustraciju (Freeman, 2001).

Navodimo primjer kako nastavnik ne treba raditi s nadarenom (i ostalom) djecom:

"Moj posljednji nastavnik matematike nije govorio šta smo dobili na testu. Nasreću, nisam želio to da znam, jer matematiku nisam radio dobro u to vrijeme. Ali, ne znam kako on očekuje da nas nešto nauči iz toga." (Freeman, 2001:140)

U redovnom/općem razredu problem u radu sa nadarenom djecom može da bude i tri puta problem. Prilikom predavanja lekcije nastavnik ${ }^{7}$ najmanje tri puta

${ }^{7}$ Navodimo nekoliko strategija koje nastavnik može koristiti u inkluzivnom razredu (Gargiulo, 2006:366): imati velika očekivanja od svih učenika; koristiti tehniku „bura mozga“, kako bi učenici postavili pitanja koja su u sklopu lekcije; izraditi KW kartu/chart kako bi učenici 
kaže istu stvar. Prvi put u uvodu - kada upoznaje učenike s temom izlaganja (Ovo je ono o čemu ću vam govoriti); drugi put u glavnom dijelu sata - kada opširnije govori o temi (Sada vam govorim o tome); treći put u završnom dijelu sata - kada sumira rečeno (Ovo je ono o čemu sam vam baš govorio). Ali, nadareni učenici zapamte suštinu već nakon prvog izlaganja. Ovaj problem Freeman (2001) naziva tri puta problem. Jedna od negativnih posljedica ovog problema je dosada.

Da bi izbjegli dosadu uzrokovanu trostrukim ponavljanjem, nadareni često koriste specijalnu tehniku. Oni se izvježbaju da svjesno slušaju samo prvi put ono što nastavnik govori o temi, a onda ne slušaju daljnja pojašnjenja.

Radi ilustracije, navodimo izjavu nadarene djevojke koja govori o problemu ponavljanja jedne lekcije više puta tokom nastavnog sata (Freeman, 2001:128):

„Prilikom predavanja, sve sam slušala samo prvi put, a kada bi počeli da govore ponovo i ponovo o istoj temi, ja bih koristila svoje 'dugme za gašenje' (isključila bih se). Ovo je počelo u školi, gdje su lekcije bile, manje ili više, date kao na pladnju. Po tonu glasa možeš reći kada počinje ponovo, posebno nakon sjedenja u klupi više sati i slušanja lekcija i predavanja, a posebno kada imaš samo jednog nastavnika. I kada bi rekli, 'Sada, dakle', ja bih pomislila: 'Uredu, sada imam pet minuta za sebe'. Zaista može biti dosadno kada se u toku predavanja o istoj stvari govori četiri puta. Imali smo jednog koji bi pitao, 'Da li neko ima neko pitanje?', $i$ svi bi šutjeli. A on bi rekao: 'Imali ste dovoljno vremena da nešto kažete, a niko ništa nije rekao, pa je očito da niko ništa nije ni razumio i ja ću sada sve da ponovim.' Ohhh!“

Opasnost od ove tehnike je u tome kad traje dovoljno dugo pa dijete propusti i prvo objašnjenje teme. Te teme mogu biti zaista važne za izgrađivanje djetetovog znanja, i to preskakanje/isključivanje može postati loša navika.

Učenje nadarenog djeteta može postati neredovno, što može zbuniti nastavnike i roditelje. Nedostatak informacija može dovesti i do pogrešnih zaključaka, kojih se dijete može čvrsto držati. Ovaj problem se može pojaviti i u školama koje su specijalizirane za nadarene, jer i između ove djece, također, postoje razlike u sposobnostima.

Da bi se izbjeglo navedeno, u razredu se može samostalno kreirati atmosfera i organizacija koja će omogućiti nastavniku da realizira nastavni plan i program, ali i poštuje individualizaciju $\mathrm{i}$ diferencijaciju ${ }^{8} \mathrm{u}$ nastavi. Jedan od dobrih načina jeste primjena Dottrensovih nastavnih listića.

iskazali što znaju i što žele znati o temi; učenicima dati listu pojmova koji se odnose na lekciju i tražiti da ih objasne. Na osnovu informacija koje se dobiju na ovaj način, moguće je planirati realizaciju naredne lekcije i učiniti da nijednom učeniku ne bude dosadno, da svi u određenom trenutku imaju primjerenu aktivnost.

${ }^{8}$ Diferencijacija i individualizacija su međusobno uvjetovane - diferencijacija nije moguća bez individualizacije, i obrnuto. Diferencijacija nastave znači svakom učeniku omogućiti da uspostavi vlastiti ritam učenja i da svojim tempom stigne do cilja (Biondić, 1993). To bi značilo da u prvom planu nije nastavni plan i program, već učenik i njegove potrebe, znanje, interesi, sposobnosti.

Diferencijacija je (Gaugilo, 2006: 363): imati visoka očekivanja za sve učenike; ako su mnogostruka ustupanja unutar jedinice orijentirana prema učenicima različitih nivoa postignuća; 
Individualizirani rad u nastavi za Dottrensa ${ }^{9}$ znači omogućiti svakom učeniku da radi onako kako njemu odgovara. To nije cilj za sebe, već sredstvo za osiguranje djetetovog razvoja. "Individualizovani rad se po našem shvatanju ne sastoji u tome da svi rade individualno isti posao, već da se za svakog bira poseban rad koji mu odgovara. Mi, isto tako, ne gledamo na individualizovani rad kao na cilj sam po sebi već kao na sredstvo koje treba zajedno s drugima da se upotrebi da bi se detetu obezbedio normalan razvoj i bolje izgrađivanje njegovog duha." (Dottrens; 1962:27)

\section{Nastavni listići Roberta Dottrensa}

Nastavni listići su značajan oblik individualizacije nastave. Imaju veliku didaktičku vrijednost $\mathrm{u}$ organizaciji nastave. Na svakom listiću daje se po jedan zadatak (ali može biti i više srodnih), a uz njega uputstvo za rad. Učenici zadatke rješavaju samostalno, a uz mogućnost provjeravanja i korištenja tačnih odgovora vrši se provjera ili samoprovjera, čime se uspostavlja povratna sprega, odnosno povratna informacija. Odgovori se, najčešće, nalaze na poleđini listića, ili su izdvojeni posebno (npr. u kutiji za nastavne listiće, ili na nastavnikovom stolu). Zadaci mogu biti različiti (problemski, grafički, tekstualni i slično). Za učenike različitog nivoa znanja (sposobnosti) pripremaju se zadaci različiti po težini, što omogućava diferenciranje nastave. Svaki učenik dobiva različit zadatak, i to postupnim redom, prema težini.

Korištenje nastavnih listića ima bitan obrazovni, odgojni i funkcionalni značaj. Učenici su u prilici da uče manje poznato gradivo, da napreduju odgovarajućim tempom, omogućava se potpunija individualizacija nastavnog rada, što dovodi do potpunijeg aktiviranja svih učenika u odjeljenju. Putem nastavnih listića učenici se osposobljavaju za permanentno obrazovanje, razvijaju im se navike samostalnog rada i osposobljavaju se za korištenje knjigom i raznovrsnim izvorima znanja. Učenik brzo dobiva povratnu informaciju, tako da to predstavlja snažnu motivaciju za naredne aktivnosti. U procesu korištenja nastavnih listića učenik je ne samo redovno i pravovremeno informiran da li je i u kojoj mjeri savladao određeno gradivo, već se postepeno upućuje i u odgovarajuće oblike i postupke samokontrole, koja ima visoku pedagošku vrijednost.

dopustiti učenicima da biraju, uz pomoć nastavnika, načine učenja i kako da pokažu ono što su naučili; dozvoliti učenicima da pokažu vladanje materijom, šta već znaju, i napredak kroz novi materijal njihovim vlastitim koracima; odrediti nekoliko aktivnosti koje traže različite stilove učenja, nivoe razmišljanja, interesne nivoe i nivoe postignuća; ako učenici imaju mogućnost da biraju šta će učiti; fleksibilnost. Diferencijacija nije mnogo toga, a izdvajamo nekoliko elemenata (Gaugilo, 2006: 363): individualizacija; davati učenicima isti rad/zadatak stalno; cijelo vrijeme/stalno, često je prednost za učenike da rade kao cijelo odjeljenje; ograničiti akceleraciju.

${ }^{9}$ Robert Dottrens (rođen 1893), švicarski pedagog, postao je poznat po modelu nastave koji karakterizira naglašena briga za napredovanje svakog pojedinog učenika. Slabosti kolektivne frontalne nastave Dottrens i saradnici su pokušali prevladati izradom i korištenjem nastavnih listića. Individualizacija nastave uz pomoć nastavnih listića provjeravana je u eksperimentalnoj školi u Mailu (Švicarska), koja je počela raditi 1928. godine. Ova škola je imala dvadesetak odjeljenja, od prvog do šestog razreda, a služila je i kao vježbaonica za buduće nastavnike. 
Učenje putem nastavnih listića vrlo je aktivan oblik nastavnog rada. Učenici su angažirani u skladu sa svojim psihofizičkim sposobnostima i u prilici su da obavljaju različite misaone operacije: analizu, sintezu, komparaciju, generalizaciju i slično. Naravno, prilikom izrade nastavnih listića neophodno je voditi računa o kompoziciji zadataka. Treba se pridržavati poznatih principa: od lakšeg ka težem, od poznatog ka nepoznatom, od jednostavnog ka složenijem. Nastavni listići se mogu koristiti za sve tipove časova, ali su za utvrđivanje i ponavljanje gradiva najpraktičniji. Vremenska dimenzija rada na nastavnim listićima može trajati od nekoliko minuta do cijelog časa, u zavisnosti od postavljenog cilja, raspoloživog vremena i slično.

Treba reći da se ispravka vrši neposredno, dok svaki učenik radi svoj poseban zadatak. Čim učenik završi jednu seriju ili listić, prema slučaju, odlazi do nastavnika koji pregleda njegov zadatak i daje mu uputstva za dalji rad. Premještanje se vrši brzo i u tišini, te ovaj način ispravljanja zadataka nimalo ne uznemiruje učenike, koji se vrlo brzo naviknu na ovakav sistem. On utemeljuje određeni režim discipline, koji nije bio predviđen u Dottrensovim eksperimentima, ali je veoma bitan.

Uloga nastavnika u ovom procesu je veoma zahtjevna. Nastavnik ima velike obaveze u pripremanju ove nastave. Da bi uspješno primijenio individualiziranu nastavu, mora dobro poznavati individualne razlike među učenicima, jer bez toga nema individualizacije. Nastavnik u radu treba da ostavlja veliku slobodu onima koji brzo shvataju i da im dozvoli da napreduju, a da učenicima koji sporije napreduju daje potrebna objašnjenja.

\section{Vrste nastavnih listića} u nastavi:

Dottrens (1962:57) navodi četiri vrste nastavnih listića koji se mogu koristiti

1. listići za nadoknađivanje, ${ }^{10}$

2. listići za razvoj,

3. listići za vježbanje, ${ }^{11}$

4. listići za samostalno učenje. ${ }^{12}$

${ }^{10}$ Listići za nadoknađivanje služe da učenici ovladaju bitnim sadržajima i tehnikama koje u ranijem učenju nisu savladali ili su zaboravili.

${ }^{11}$ Listići za vježbanje služe da se učenici postepeno uvježbavaju u onim oblastima gdje je vježbanje neophodno, npr.maternji jezik, pravopis.

${ }^{12}$ Listići za samostalno učenje su takva vrsta nastavnih listića koji sadrže vježbe koje podstiču na posmatranje, koje podstiču učenika da sebi postavlja mnogobrojna pitanja na koja, u većini slučajeva, može odgovoriti samo ukoliko odluči da razmišlja o njima. Dottrens ističe da naziv ove vrste listića nije baš najsretnije izabran, ali da je ovaj izraz najbliži za označavanje vježbanja pri čijem izvođenju učenici, zaista, imaju iluziju da uče sami. Umjesto ponovnog potpunog izlaganja, učenici napreduju polako i pouzdano, a nastavnik odmah zapaža nedostatke i teškoće svakog učenika. 
Iz ovog popisa izdvajamo listiće za razvoj. Pogotovo listići za razvoj mogu biti korišteni u radu sa nadarenim učenicima u razredu. Nakon što nadareni učenici shvate što je suština teme o kojoj nastavnik govori taj čas, nadarenim učenicima se ponude listići za razvoj i na taj način se sprečava nastajanje dosade i nepolježnih oblika ponašanja.

Listići za razvoj su nastali zahvaljujući jasnom cilju: iskoristiti trenutke koje su iznadprosječni učenici gubili čekajući na svoje vršnjake iz razreda, sve kako bi nastavnik mogao prijeći na drugu lekciju. Dok se listići za nadoknađivanje temelje na namjeri da svi učenici usvoje minimalan program, ${ }^{13}$ ovi drugi se zasnivaju na drugom dijelu programa, a to je program za razvoj. Listići za razvoj omogućuju izlaženje iz okvira školskog rada, izoštravanje bistrine učenika i mogućnosti za mnogo drugih saznanja, uvođenje aktuelnih događaja u nastavu, pitanja koja dublje zalaze u neki dio nastave i slično. Sa ovom vrstom listića Dottrens i saradnici su postigli veliki uspjeh. Ovo je za sve učenike bio jak podsticaj, pa su čak i smišljali zadatke za ovu vrstu nastavnih listića.

Ova vrsta nastavnih listića je veoma korisna u odgojnoobrazovnom radu s nadarenim učenicima, da im - kada završe zadatke prije ostalih učenika, ili shvate ono što nastavnik govori - ne bi bilo dosadno i da ne bi stvarali nered u razredu.

Primjer listića za razvoj (I razred) ${ }^{14}$ :

1. Kako ti je ime? Kako ti je prezime? U kojoj ulici stanuješ? U koju školu ideš? Koje godine si rođen?

2. Ljet

Zimi

a) kližemo se, b) kupamo se u jezeru, c) jedemo trě̌nje, d) zagrijavamo kuću, f) ptice pjevaju, g) nosimo toplo odijelo.

3. Nacrtaj buket od 9 cvjetova i oboji 3 cvijeta žutom, 3 crvenom i 3 rozom bojom!

4. Koje bi namirnice (od hrane) izdvojio za pravljenje kolača: brašno, jaja, šećer, orasi, so, biber, paprika, čokolada, kokos, paradajz, marmelada, mlijeko.

5. Kupus, paradajz, jagoda, grah, trě̌nja, kruška, mrkva, repa, grašak, narandža.

Povrće:

${ }^{13}$ Dottrens (1962) ističe da svaki nastavni program prešutno ima dva dijela: minimalni program - zbir pojmova koje učenici trebaju obavezno usvojiti da bi prešli u stariji razred, i program za razvoj - koji se ostavlja inicijativi nastavnika da upotpuni znanje i kulturu svojih učenika.

${ }^{14}$ neki od zadataka su preuzeti iz: Dottrens (1962: 64) 
Voće:

Listići za samostalno učenje bi, također, mogli biti zanimljivi u odgojnoobrazovnom radu s nadarenim učenicima. Istina, prema Dottrensovom objašnjenju vidimo da su to listići koji se primjenjuju kada nastavnik ispredaje cjelokupnu lekciju, i da to ne bi morao ponovo raditi, učenicima se daju nastavni listići na kojima je operacionalizirana tema. Ova vrsta nastavnih listića može biti korisna u radu s nadarenim učenicima, ukoliko bi nastavnik već u toku prvog izlaganja lekcije nadarenim učenicima dao nastavne listiće da rade $i$ na taj način ih uključio $u$ nastavnu jedinicu, za vrijeme dok on objašnjava ostalim učenicima. Na ovaj način nadareni učenici ne bi imali potrebu da se isključuju iz predavanja nastavnika. Nastavni listići bi mogli biti kvalitetan oblik rada s nadarenim učenicima, te način primjene individualizacije i diferencijacije u odgojno-obrazovnom radu. Zbog mogućnosti da se pomoću njih detaljnije obradi neka tema, moguće ih je uvrstiti u metodički oblik obogaćivanja nastave.

Sve pokazuje da su nastavnici izuzetno važni u cjelokupnom razvoju i odgojno-obrazovnom radu s nadarenom djecom. Oni su bitni u prepoznavanju znakova koji ukazuju da neko dijete ima iznadprosječne sposobnosti, jer su u direktnom, svakodnevnom kontaktu sa djecom; bitni su u fazi identifikacije djece koja posjeduju iznadprosječne sposobnosti i, naravno, u odgojnoobrazovnom radu s nadarenom djecom.

Pigmalion efekat (Nikolić, 1997) potvrđuje da nastavnici mogu mnogo učiniti da bi učenici razvili svoje sposobnosti do mogućeg maksimuma. Pod ovim terminom se označava načelo po kojem je uspjeh djeteta, ustvari, rezultat očekivanja nastavnika.

Prvo iskustvo te vrste stekli su američki psiholozi Rosenthal i Jacobson u jednoj školi u SAD-u, od 1964. do 1966. godine. Na osnovu istraživanja oni su sastavili listu djece koja su trebala uspjeti. Međutim, djeca su uzeta nasumice, a lista je predana nastavnicima $\mathrm{i}$ rečeno im je da su to djeca $\mathrm{s}$ iznadprosječnim sposobnostima te da će sigurno uspjeti. Kasnije, u različitim vremenskim razmacima, djeca su testirana, da se odredi koliko, za koje vrijeme i u kojem predmetu su djeca s liste napredovala u odnosu na učenike u razredu. Pokazalo se da su ova djeca, uglavnom, napravila neočekivan napredak. Istraživanju su, istina, upućene brojne metodološke kritike, te upozorenje da rezultate treba uzimati $\mathrm{s}$ najvećim oprezom. Ali, ipak, smatra se da, zaista, postoji određen odnos između očekivanja nastavnika u odnosu na neku djecu, i njihovih rezultata u školi. Ako su djeca koja su imala iznadprosječne sposobnosti (a bilo je, sigurno, i takve djece u ovoj grupi slučajno izabrane djece) postigla značajan napredak, koliko bi tek mogli napredovati oni kojima bi se, uz pomoć prepoznavanja i identifikacije, zaista utvrdilo da su nadarena i posjeduju iznadprosječne sposobnosti te odgovarajuće osobine ličnosti. 


\section{Zaključak}

Nadareni učenici su veliki izazov za nastavnike i cjelokupni obrazovni sistem. Nije jednostavno poučavati nadarene učenike, jer njima treba više znanja, pažnje i podrške. Autori su razmatrali koje osobine trebaju imati nastavnici koji poučavaju nadarene učenike.

U tom smislu spominju se različite osobine, kao npr: kreativnost, fleksibilnost, tolerancija, entuzijazam. S druge strane, postoje i istraživači, kao, npr., Baldwin (1993), koji smatraju da svi stručni, pravi nastavnici imaju osobine, sposobnosti i znanje da poučavaju nadarene učenike.

Nastavnici su važni u cjelokupnom procesu rada s nadarenim učenicima. Bitni su u fazi prepoznavanja, jer oni su ti sa kojima djeca provode više sati tokom dana (posebno je to slučaj kod razredne nastave) i trebalo bi da dobro poznaju sve učenike. Na taj način oni mogu prepoznati učenike koji imaju neke od karakteristika koje ukazuju da dijete ima iznadprosječne sposobnosti. Nastavnici obavezno učestvuju i u identifikaciji nadarenih učenika, a posebno u realizaciji odgojnoobrazovnog rada primjerenog nadarenom učeniku.

Ukoliko nisu ispoštovani navedeni koraci, moguće su različite negativne posljedice. Jedna od posljedica neadekvatnog rada $\mathrm{s}$ nadarenom djecom jeste dosada. Iz nje se rađaju mnogi problemi i nepoželjni oblici ponašanja. Da bi se odbranili od dosade na času uzrokovane tri puta problemom, nadareni učenici često se koriste specijalnom tehnikom vlastitog isključivanja iz zbivanja u odjeljenju. Nastavnici prilikom izlaganja jedne lekcije u toku časa o tom problemu govore najmanje tri puta. Nadareni učenici shvate suštinu teme već nakon prvog dijela izlaganja, tako da se ostatak časa dosađuju. Da bi se ovo izbjeglo, moguće je nastavnicima sugerirati da individualiziraju nastavu koristeći nastavne listiće. U ovom smislu najviše je postigao Robert Dottrens, koji navodi da postoje četiri vrste nastavnih listića. To su: listići za nadoknađivanje, listići za razvoj, listići za vježbanje i listići za samostalno učenje. Za rad sa nadarenom djecom u nastavi najinteresantniji su listići za razvoj. Oni omogućavaju izlaženje iz okvira školskog rada, izoštravanje bistrine učenika i mogućnosti za mnogo drugih saznanja, uvođenje aktuelnih događaja u nastavu, pitanja koja dublje zalaze u neki dio nastave i slično. Dok nastavnik dobija mogućnost da obrađuje novu lekciju, nadareni učenici mogu produbljivati svoje znanje iz drugih oblasti. Rad nastavnika u nastavi uz korištenje nastavnih listića je zahtjevniji, ali će dugoročno dovesti do pozitivnih efekata i nadarena djeca će biti zadovoljnija. Nastavnici ne bi trebali zaboraviti naročito jednu od osam bolnih tačaka nadarene djece (Galbraight, 1985; prema: Hallahan\&Kauffman, 1997:468): „Ono što se uči u školi je lagano i dosadno.“

Naravno, nastavnici moraju imati društvenu podršku i adekvatno obrazovanje za rad s nadarenom djecom, jer nadarena djeca su bogatstvo svakog društva. Kako ističe Freeman (2001:1): „...Iako su nadareni samo osobe, oni su, također, i nacionalni resursi, i budućnost svakog društva ovisi o razvoju potencijala mladih ljudi. Nijedna zemlja ne može sebi priuštiti da ih izgubi“ (naglasila: L. K), a posebno Bosna i Hercegovina. 


\section{Literatura}

Ajanović, Dž. \& Stevanović, M. (1998); Školska pedagogija; Sarajevo: Prosvjetni list

Biondić, I. (1993); Integrativna pedagogija; Zagreb: Školske novine

Chan, D.W. (2001); Characteristics and Competencies of Teachers of Gifted Learners: The Hong Kong Teacher Perspective; Roeper Review, Vol. 23

Cvetković-Lay, J. (2002); Darovito je, što ću sa sobom?; Zagreb: Alinea

Cvetković-Lay, J. i Sekulić-Majurec, A. (1998); Darovito je, što ću sa njim?; Zagreb: Alinea Routledge

Dean, J. (1996); Managing Special Needs In the Primary School; London:

Dottrens, R. (1962); Individualizovana nastava; Sarajevo: Veselin Masleša

Drašković, B. (1998); Daroviti i obrazovna odiseja; Beograd: ABC Grafika

Ewgblada, P.A. (1987); Gifted and Talented Education: Its potential to benefit all children; The University of Michigan

Franković, D., Pregrad, Z. (ured.) (1963); Enciklopedijski rječnik pedagogije; Sarajevo: Svjetlost

Freeman, J. (2001); Gifted children growing up; London: The Cromwell Press, Trowbridge, Wilts.

Furlan, I. \& Kobola, A. (1971); Ubrzano napredovanje nadarenih učenika osnovne škole; Zagreb: Školska knjiga

Gargiulo, M.R. (2006); Special Education in Contemporary Society - An Introduction to Exceptionality; Thomson Wadsworth

Hallahan, P. D. \& Kauffman, M. J. (1997); Exceptional Children-Introduction to special education; Allyn and Bacon

Kneedler, D. R., Hallahan, P. D. \& Kauffman, M. J. (1984); Special Education for Today; New Jersey: Prentice-Hall, Inc.

Koren, I. (1989); Kako prepoznati i identificirati nadarenog učenika; Zagreb: Školske novine istraživanja

Maksić, B. S. (1998); Darovito dete u školi; Beograd: Institut za pedagoška

Muminović, H. (2000); Mogućnosti efikasnijeg učenja u nastavi; Sarajevo: DES

Nikolić, S. (1997); Svijet dječje psihe; Zagreb: Prosvjeta

Službene novine Kantona Sarajevo, 10/04

Wade, B. \& Moore, M. (1987); Special children, special needs: provision in ordinary classrooms; London: Robert Royce Ltd.

Young, P. \& Tyre, C. (1992); Gifted or Able? Realizing Children's Potential; Buckingham: Open University Press

www.nadarenost.net 